\title{
Gauging US and EU Seal Regimes in the Arctic against Inuit Sovereignty
}

\author{
Michael Fakhri
}

1

\section{Introduction}

It is worth comparing US and EU Arctic power because both have had an ambivalent policy position on the Arctic; and both have recently started to devote significant political and financial resources towards a coherent Arctic strategy.

The Us intensified its Arctic policy on 12 January 2009, when the George W. Bush administration released a presidential directive establishing a new policy for the Arctic region. ${ }^{1}$ On 10 May 2013, Barack Obama's administration released a document entitled National Strategy for the Arctic Region supplementing the 2009 directive. ${ }^{2}$ With the directive and strategy in tow, the Obama administration was very politically active in the Arctic as highlighted by several events: In May 2011, as part of the Us chairmanship of the Arctic Council, Secretary of State Hillary Clinton attended the Arctic Council ministerial meeting, held in Nuuk, Greenland accompanied by us Interior Secretary Ken Salazar. They were the first us Cabinet members to attend an Arctic Council meeting. In February 2014, the Obama administration appointed retired Coast Guard Admiral Robert J. Papp, Jr. as the first Special Representative

* Michael Fakhri, Associate Professor, University of Oregon School of Law, United States of America.

1 National Security Presidential Directive 66/Homeland Security Presidential Directive 25 (2009). The first federal policy addressing the Arctic was by Richard Nixon in his two-page National Security Memorandum 144 (1972); this was followed by Ronald Regan with National Security Directive 90 (1993). In 1994, Bill Clinton issued Presidential Directive 26-but this was not publically circulated and received little attention. See Chanda L. Meek and Emily Russell, 'The Challenges of American Federalism in a Rapidly Changing Arctic' in Dawn Alexandrea Berry, Nigel Bowles and Halbert Jones (eds), Governing the North American Arctic (Palgrave Macmillan UK 2016); Michael T. Corgan, 'The USA in the Arctic: Superpower or Spectator?' in Lassi Heininen (ed), Security and Sovereignty in the North Atlantic (Palgrave Macmillan UK 2014).

2 National Strategy for the Arctic Region (2013) < https://obamawhitehouse.archives.gov/sites/ default/files/docs/nat_arctic_strategy.pdf $>$ accessed 19 July 2017.

(C) MICHAEL FAKHRI, 2017 | DOI 10.1163/9789004349179_009

This is an open access chapter distributed under the terms of the CC-BY-NC License hael Fakhri - 9789004349179 
for the Arctic Region. And in September 2015, during Obama's trip to Alaska was the first time a us president travelled north of the Arctic Circle. It was also the longest and most engaged visit a sitting president made to Alaska since $1923 .^{3}$ All of these events were to some degree the Us exercising its political muscle in international Arctic politics. This was also the Obama administration's attempt to try to bring Arctic policy home and direct domestic attention due north. As Special Representative Papp recently stated, '[Americans] are detached from our Arctic. Alaskans understand it, but the rest of the country really doesn't think about the United States being an Arctic nation.' ${ }^{4}$

Finland was the first to push the EU towards developing an Arctic policy when in 1997, as part of its first EU presidency, it put forward the Northern Dimension policy. This was then approved by the European Council in 2000. ${ }^{5}$ The Northern Dimension policy raised more questions than answers and commentators continued to wonder what the EU's role in the Arctic was and should be. ${ }^{6}$ The European Commission then produced two official Communications

3 Dermot Cole, 'Since Harding in 1923, Presidential Stops in Alaska Have Brought the Unexpected and Memorable' Alaska Dispatch News (Anchorage, 28 August 2015) <https:// www.adn.com/we-alaskans/article/presidential-journeys-alaska-and-lesser-momemts -history/2015/08/29/> accessed 19 July 2017; Klaus J Dodds, 'Northward Ho! Obama, Diefenbaker and the North American Arctic' (2016) 52(2) Polar Record 252; Ronald O'Rourke, Congressional Research Service, 'Changes in the Arctic: Background Issues for Congress' (R41153, 31 May 2016) <https://fas.org/sgp/crs/misc/R41153.pdf> accessed 19 July 2017.

4 Erica Martinson, 'Now Trending in DC: Arctic Issues' Alaska Dispatch News (Washington, DC, 10 June 2016) <https://www.adn.com/arctic/2016/o6/10/now-trending-in-dc-arctic-issues/> accessed 19 July 2017. See also Philip E. Steinberg, 'US Arctic Policy: Reproducing Hegemony in a Maritime Region' in Robert W Murray and Anita Dey Nuttall (eds), International Relations and the Arctic: Understanding Policy and Governance (Cambria Press 2014); Donald R Rothwell, 'The United States and Arctic Straits: The Northwest Passage and the Bering Strait' in Suzanne Lalonde and Ted L. McDorman (eds), International Law and Politics of the Arctic Ocean (Brill 2015).

5 European Council, Action Plan for Northern Dimension with External and Cross-border Policies of the European Union 2000-2003 (14 June 2000) Doc. No. 9401/oo NIS 78.

6 Hanna Ojanen, 'The EU and Its' Northern Dimension': An Actor in Search of a Policy, or a Policy in Search of an Actor?' (2000) 5(3) European Foreign Affairs Review 359; Moritz Pieper and others, 'The European Union as an Actor in Arctic Governance' (2011) 16(2) European Foreign Affairs Review 227; Andreas Østhagen, 'The European Union-An Arctic Actor?' (2013) 15(2) Journal of Military and Strategic Studies 71; Kamrul Hossain, 'EU Engagement in the Arctic: Do the Policy Responses from the Arctic States Recognise the EU as a Legitimate Stakeholder?' (2015) 6(2) Arctic Review on Law and Politics 89. 
in 2008 and 2012. ${ }^{7}$ Despite these two Communications, most EU politicians and policymakers remained ambivalent to the Arctic. In response, some commentators argued that it was in the EU's interest to devise a rigorous Arctic policy that was more coherent than the piecemeal initiatives to date. ${ }^{8}$ On 27 April 2016 the EU released its most articulate position to date with its Integrated Policy for the Arctic. ${ }^{9}$

While both the Us and Eu have published new policy documents, their relationship to the Arctic is still unclear. They have framed their Arctic political activity in terms of matters of environment, sustainable development energy and security and it remains to be seen how each authority will pursue an agenda that navigates these multiple—and at times competing—demands. ${ }^{10}$

European Commission, The European Union and the Arctic Region (11 November 2008) <eeas.europa.eu/arctic_region/docs/com_08_763_en.pdf> accessed 17 October 2016; European Commission and the High Representative of the European Union for Foreign Affairs and Security Policy, Developing a European Union Policy Towards the Arctic Region: Progress Since 2008 (26 June 2012) <https://eeas.europa.eu/arctic_region/docs/ join_2012_19.pdf $>$ accessed 17 October 2016.

8 Kristine Offerdal, 'The EU in the Arctic: In Pursuit of Legitimacy and Influence' (2011) 66(4) International Journal 861; Steffen Weber and Iulian Romanyshyn, 'Breaking the Ice: The European Union and the Arctic' (2011) 66(4) International Journal 849; Timo Koivurova and others, 'The Present and Future Competence of the European Union in the Arctic' (2012) 48(4) Polar Record 361; Antje Neumann, 'European Interests as Regards Resource Exploitation in the Arctic: How Sustainable Are European Efforts in This Regard?' (2012) 4 Yearbook of Polar Law 619; Mar Campins Eritja, 'European Union and the North: Towards the Development of an EU Arctic Policy, The Polar Oceans Governance' (2013) 27 Ocean Yearbook 459; Kathrin Keil and Andreas Raspotnik, 'The European Union's Gateways to the Arctic' (2014) 19(1) European Foreign Affairs Review 101; Cécile Pelaudeix, 'China's Interests in the Arctic and the EU's Arctic Policy: Towards a Proactive EU Foreign Policy?' (2015) 7 Yearbook of Polar Law 128; Vicente Lopez-Ibor Mayor, 'The EU Needs a New Arctic Strategy' (2016) 7(1) Global Policy 119 .

9 Joint Communication of the European Commission and High Representative of the European Union for Foreign Affairs and Security Policy of 27 April 2016 on An Integrated European Union Policy for the Arctic, JOIN (2016) $21<$ https://eeas.europa.eu/arctic region/docs/160427_joint-communication-an-integrated-european-union-policy-for-thearctic_en.pdf > accessed 17 October 2016.

10 Stéphane Roussel and John Erik Fossum, 'The Arctic Is Hot Again in America and Europe: Introduction to Part I' (2010) 65(4) International Journal 799; Patrizia Vigni, 'The Governance of the Arctic Environment: The EU and US Contribution' in Christine Bakker and Francesco Francioni (eds), The EU, the US and Global Climate Governance (Ashgate 2014); Adam Stępień, 'Internal Contradictions and External Anxieties: One "Coherent" Arctic Policy for the European Union?' (2015) 7 Yearbook of Polar Law 249; Adam Stępień and Andreas Raspotnik, 'The EU's New Arctic Communication: Not-So-Integrated, NotSo-Disappointing?' (Arctic Institute, 2015) <http://www.arcticcentre.org/blogs/The-EU\% 
Moreover, within the Us and EU, the degree of political interest in the Arctic remains uneven. ${ }^{11}$

Political uncertainty has not meant inaction and both the US and EU have enacted laws that have effected Arctic inhabitants. Some of the most controversial legislation has been seal hunting moratoriums that have provided an exception for indigenous hunters. In this chapter, I compare the respective seal regimes - the Us marine mammal conservation laws and the EU trade import ban-because seal hunting is a practice that not only provides sustenance and income to Inuit and other indigenous peoples, it is also defines self-hood in the Arctic. I therefore consider the Us and EU's respective seal regimes as a principal way each authority negotiates its relationship with Arctic indigenous communities and expresses power in the Arctic.

I will first explain my analytical approach. I then argue that even though the US and EU have new policies, their relationship to the Arctic remains uncertain partly because geographic concepts about the Arctic itself are complex. After, I study the us seal regime and how it relates to indigenous hunting rights-I show that what is at stake in the governing of seals is sovereign power in the Arctic. From the experiences in Alaska, I treat sovereignty as a method of analysis to examine the EU seal regime.

\section{Sovereignty as an Analytical Concept}

Before commencing the legal study, I should explain how I use sovereignty as an analytical concept since the term is inherently contentious. One way to understand sovereignty is as an exclusive exercise of power over a determined territory by a single authority. But this concept does not capture the multiple ways that sovereignty is expressed and defined in practice. ${ }^{12}$ Sovereignty is

E2\%80\%99s-new-Arctic-Communication-not-so-integrated,-not-so-disappointing/ ne2t4glg/65469626-3128-4ae2-96e3-c38b75cf387d > accessed 19 July 2017.

11 Philip E. Steinberg, 'Maintaining Hegemony at a Distance: Ambivalence in US Arctic Policy' in Richard C. Powell and Klaus Dodds (eds), Polar Geopolitics?: Knowledges, Resources and Legal Regimes (Edward Elgar 2014); see also Østhagen, n. 6 above.

12 Jean L. Cohen, 'Whose Sovereignty? Empire Versus International Law' (2004) 18(3) Ethics \& International Affairs 1; Antony Anghie, 'Rethinking Sovereignty in International Law' (2009) 5(1) Annual Review of Law and Social Science 291; Martti Koskenniemi, 'What Use for Sovereignty Today?' (2011) 1(1) Asian Journal of International Law 61; Betsy Baker, 'International Law and the Arctic: How Territoriality, Human Rights, and Sovereignty Can Shape Sovereignty' in Robert W Murray and Anita Dey Nuttall (eds), International Relations and the Arctic: Understanding Policy and Governance (Cambria Press 2014); GuySerge Côté and Matthew Paterson, 'Ecological Sovereignty and Arctic Politics' in Robert W. 
pluralist and relational, involves the regular negotiation of authority and jurisdiction, and constitutes a complex relationship to land.

While sovereignty is about the authority to rule over people and things within a particular territorial jurisdiction, it is not necessarily established through military exercises, flag planting, or regular scientific expeditions. Instead, I take sovereignty as a historically contingent concept, which in the Arctic can be understood within the context of Inuit and other indigenous peoples' long history of struggle to gain recognition and respect.'13 I do not assume that sovereignty over land and territory in the Arctic (or anywhere for that matter) is something that is ever determinatively settled. ${ }^{14}$ Instead, it is a concept that people deploy in different ways when they argue over who gets to create the rules and institutions that govern territory. Thus, examining international legal and political disputes as disagreements amongst sovereigns may not completely capture political dynamics in a case; it may be more illuminating to understand what is at stake by examining how sovereign power is defined through those disputes.

In order to better understand the stakes it also helps to make a distinction between the concepts of self-determination and sovereignty, even though their meanings significantly overlap and people often use the terms interchangeably. I understand self-determination as a group's ability to obtain their needs and express their desires within an existing system - to play the game in a way that serves their own interest. Sovereign power is a group's ability to define the rules of the game and determine the space in which those rules apply.

I will show how due to a particular colonial and legal context, debates about seal hunting (and other hunting rights) — not claims in terms of land title or maritime boundaries - are one significant way that contemporary sovereignty is understood, contested, and negotiated in Alaska. By using sovereignty as way to organize legal concepts, the fight over seal hunting laws becomes a story about the broader jockeying for control and authority in the Arctic. The EU is not making direct claims to any land or seaways in the Arctic, but as two residents of the North Slope Borough in Alaska explain, 'Regulation of animals

Murray and Anita Dey Nuttall (eds), International Relations and the Arctic: Understanding Policy and Governance (Cambria Press 2014); Jessica M. Shadian, The Politics of Arctic Sovereignty: Oil, Ice, and Inuit Governance (Routledge 2014).

13 A Circumpolar Inuit Declaration on Sovereignty in the Arctic (April 2009) para. 2.1 <http:// iccalaska.org/wp-icc/wp-content/uploads/2016/o1/Signed-Inuit-Sovereignty-Declaration11x17.pdf $>$ accessed 17 October 2016.

14 Contra Michael Byers, International Law and the Arctic (Cambridge University Press 2013) 10-16, 235; David L. VanderZwaag and Jonathan R. Edge, 'Canada-Russia Relations in the Arctic: Conflictual Rhetoric, Cooperative Realities' in Suzanne Lalonde and Ted L. McDorman (eds), International Law and Politics of the Arctic Ocean (Brill 2015) 242. 
extends to regulating the land and water on and in which the animals live, which then leads to "regulating" people by restricting their activities. ${ }^{15}$ The meaning of seal hunting and the implications of the law become even more complicated when considering how seal hunting connects to a global economy. ${ }^{16}$ Sovereignty, therefore, serves as a useful concept to examine how the Eu's new seal regime changes how different bodies exercise authority and jurisdiction over Inuit seal hunting practice and commerce.

Also, I take claims to sovereign power to be only as legitimate and as good as one's relation to Arctic indigenous communities. Or as Mary Simons, former President of Inuit Tapiriit Kanatami, famously put it in the context of Canada, 'Sovereignty begins at home.'17 The international corollary is that 'Arctic sovereignty begins with Inuit [and indigenous peoples].'18 This is true for all Arctic states, but especially true for the US and EU since they have such a historically and geographically equivocal Arctic presence. Thus, the EU seal regime should be measured against contemporary Arctic legal and political developments in which indigenous peoples are granted at least autonomous legal and procedural standing as a right. ${ }^{19}$

In sum-since indigenous peoples such as the Inuit have a clear claim to their presence in the Arctic, only by gauging and comparing the Us and Eu's relationship to indigenous communities can one truly understand how us and EU power operates in the Arctic. ${ }^{20}$

15 Glenn W. Sheehan and Anne M. Jensen, 'Emergent Cooperation, Or, Checkmate by Overwhelming Collaboration: Linear Feet of Reports, Endless Meetings' in Rebecca Pincus and Saleem H. Ali (eds), Diplomacy on Ice (Yale University Press 2015) 215.

16 Gary Kofinas, 'Subsistence Hunting in a Global Economy: Contributions of Northern Wildlife Co-Management to Community Economic Development' (1993) 4 Making Waves: A Newsletter for Community Economic Development Practioners in Canada <http://arctic circle.uconn.edu/NatResources/subsistglobal.html> accessed 20 September 2016.

17 Mary Simon, 'Inuit and the Canadian Arctic: Sovereignty Begins at Home' (2009) 43(2) Journal of Canadian Studies/Revue d'études canadiennes 250.

18 ICC Canada Staff, 'Arctic Sovereignty Begins with Inuit' (2008) 1(4) DRUM $1<$ http:// iccalaska.org/wp-icc/wp-content/uploads/2016/o1/December-2008-Drum.pdf > accessed 17 October 2016.

19 Timo Koivurova, 'The Status and Role of Indigenous Peoples in Arctic International Governance' (2011) 3 Yearbook of Polar Law 169; Leena Heinämäki, 'Towards an Equal Partnership between Indigenous Peoples and States: Learning from Arctic Experiences?' (2011) 3 Yearbook of Polar Law 193; Antje Neumann, 'Indigenous Peoples' Participation in the Context of Area Protection and Management: International Approaches versus Regional Approaches in the Arctic' (2011) 3 Yearbook of Polar Law 247.

20 Inuit, like all people, are always defining and redefining the nature and meaning of that claim, see for example A Circumpolar Inuit Declaration on Sovereignty in the Arctic 
Even though both the Us and EU have new revitalized Arctic policy agendas, their geopolitical relationship to the Arctic remains a matter of debate. This stems in part by the fact the 'Arctic' is a multifaceted concept. The Arctic may be understood in various geographic terms: the area north of Arctic Circle (latitude 66 degrees, 32 minutes north), north of the tree line (which roughly follows the $10^{\circ} \mathrm{C}$ summer isotherm), or the territory surrounding the Arctic Ocean. Instead of thinking of the Arctic as having a particular boundary you get a better understanding of Arctic geopolitics if you think of it as 'structurally more of a multifold extension of the northerly regions of the eight Arctic states.21 If you think in these terms, the Arctic is then defined by how those States and their citizens deploy a complex mix of domestic and international laws to govern the North.

By any geographic definition, the us Federal Government may claim to be an Arctic power because of the fact that part of Alaska is situated in the Arctic Circle. Nonetheless, many residents in Alaska will use the phrase 'Alaska and the United States' designating an indefinite relationship between what is now the State of Alaska and the 48 states that comprise the contiguous continental United States (the 'Lower 48'). ${ }^{22}$ The European Commission makes geographic claims to the Arctic based on the fact that three of its members, Denmark, Finland, and Sweden have territory in the Arctic Circle. But that claim is fraught with political uncertainties: Denmark's claim to Arctic geography is based on the fact that Greenland and the Faroe Islands are countries within the Kingdom of Denmark. But Greenland's autonomy and sovereignty increases every year, and the Faroese are divided over the future of their

(April 2009) <http://iccalaska.org/wp-icc/wp-content/uploads/2016/o1/Signed-InuitSovereignty-Declaration-11x17.pdf> accessed 17 October 2016; Inuit Circumpolar Council Nuuk Declaration 2010 (1 July 2010) <http://inuit.org/icc-greenland/icc-declarations/ nuuk-declaration-2010/> accessed 17 October 2016. See also Fiammetta Borgia and Paolo Vargiu, 'The Inuit Declaration on Sovereignty in the Arctic: Between the Right to SelfDetermination and a New Concept of Sovereignty?' (2012) 4 Yearbook of Polar Law 189. Of course, the Inuit Circumpolar Council like all alliances includes its own internal disagreements and tensions, see Gary N. Wilson and Heather A. Smith, 'The Inuit Circumpolar Council in an Era of Global and Local Change' (2011) 66(4) International Journal 909. Timo Koivurova, 'The Arctic Council: A Testing Ground for New International Environmental Governance' (2012) 19(1) Brown Journal of World Affairs 131, 141.

See the following for a history of the complexities of Alaska statehood, Gregory W. Kimura (ed), Alaska at 5o: The Past, Present, and Future of Alaska Statehood (University of Alaska Press 2010). 
constitutional relationship with Denmark thereby complicating Denmark's Arctic geography. ${ }^{23}$ Moreover, Greenland and the Faroe Islands, though part of the Kingdom of Denmark, are not members of the EU. Finland and Sweden are relative newcomers to the EU, joining in 1995 and have showed some leadership within the EU to develop an Arctic policy. ${ }^{24}$ Nonetheless, Sweden only recently began presenting itself as an 'Arctic' nation in foreign relations and developed its first significant Arctic strategy only in 2011;25 Finland articulated its Arctic policy only in $2010 .{ }^{26}$

The Arctic may also be understood as the space comprised by the multiple institutions that focus on Arctic life, politics, and geography. ${ }^{27}$ The Arctic Council, since its inception in 1996, has become a principal intergovernmental forum that addresses issues faced by the Arctic governments and indigenous

23 R. Adler-Nissen, 'The Faroe Islands: Independence Dreams, Globalist Separatism and the Europeanization of Postcolonial Home Rule' (2014) 49(1) Cooperation and Conflict 55; U.P. Gad, 'Greenland: A Post-Danish Sovereign Nation State in the Making' (2014) 49(1) Cooperation and Conflict 98; Jeppe Strandsbjerg, 'Making Sense of Contemporary Greenland: Indigeneity, Resources and Sovereignty' in Richard C. Powell and Klaus Dodds (eds), Polar Geopolitics?: Knowledges, Resources and Legal Regimes (Edward Elgar 2014).

24 See Ojanen, n. 6 above; Ida Holdhus, 'Developing An EU Arctic Policy: Towards a Coherent Approach?' (Master's Thesis in Peace and Conflict Studies, University of Oslo 2010) <https://www.duo.uio.no/handle/10852/12984> accessed 19 July 2017 .

25 Sverker Sörlin, 'The Reluctant Arctic Citizen: Sweden and the North' in Richard C Powell and Klaus Dodds (eds), Polar Geopolitics?: Knowledges, Resources and Legal Regimes (Edward Elgar Pub 2014). On understanding the EU's involvement in the Arctic as a mix between external and internal factors see Clive Archer, 'The Arctic and the European Union' in Robert W. Murray and Anita Dey Nuttall (eds), International Relations and the Arctic: Understanding Policy and Governance (Cambria Press 2014).

26 Lassi Heininen, 'Finland as an Arctic and European State' in Robert W. Murray and Anita Dey Nuttall (eds), International Relations and the Arctic: Understanding Policy and Governance (Cambria Press 2014).

27 The Arctic Ocean is primarily governed under the auspices of the 1982 UN Convention on the Law of the Sea. A series of relevant 'sub-regional' entities include the Nordic Council, Nordic Council of Ministers, West Nordic Council, Barents Euro-Arctic Council, Northern Dimension, and Council of Baltic Sea States, see Alyson J.K. Bailes and Kristmundur Th. Ólafsson, 'Northern Europe and the Arctic Agenda: Roles of Nordic and Other Sub-Regional Organizations' (2013) 5 Yearbook of Polar Law 45. On the Eu's role in some of these organizations see, Alyson J.K. Bailes and Kristmundur Th. Ólafsson, 'The EU Crossing Arctic Frontiers: the Barents Euro-Arctic Council, Northern Dimension, and EU-West Nordic Relations' Chapter 3. 
peoples. ${ }^{28}$ It is constituted by eight Member Countries and six indigenous Permanent Participants, all of which occupy territory in the Arctic by any geographic definition. ${ }^{29}$ The Arctic Council allows States and organizations to seek official observer status: to date this includes 13 non-Arctic States, ${ }^{30} 13$ intergovernmental and inter-parliamentary organizations, ${ }^{31}$ and 13 non-governmental organizations. ${ }^{32}$ The fact that the number of official observer applicants is increasing every year is indicative of the fact that the Arctic Council has quickly become a site of global focus and politics. In fact, some Arctic Council members worry that their power will be diluted if the Arctic Council membership is opened up too widely. ${ }^{33}$

The European Commission has been able to send observers to Arctic Council meetings on an ad-hoc basis, which means it is treated like other

28 Timo Koivurova and Pitor Graczyk, "The Future of the Arctic Council: Navigating Between Sovereignty and Security' in Robert W. Murray and Anita Dey Nuttall (eds), International Relations and the Arctic: Understanding Policy and Governance (Cambria Press 2014); Kristin Bartenstein, "The Arctic Region Council Revisited: Inspiring Future Development of the Arctic Council' in Suzanne Lalonde and Ted L. McDorman (eds), International Law and Politics of the Arctic Ocean: Essays in Honor of Donat Pharand (Brill Nijhoff 2015). On the tension between regional and Arctic Council governance see Valur Ingimundarson, 'Managing a Contested Region: The Arctic Council and the Politics of Arctic Governance' (2014) 4(1) The Polar Journal 183.

29 Canada, Denmark (including Greenland and the Faroe Islands), Finland, Iceland, Norway, Russia, Sweden, and the United States. Aleut International Association, Arctic Athabaskan Council, Gwich'in Council International, Inuit Circumpolar Council, Russian Association of Indigenous Peoples of the North, and the Saami Council.

$30 \quad$ France, Germany, the Netherlands, Poland, Spain, Switzerland, United Kingdom, People's Republic of China, Italy, Japan, South Korea, Singapore, and India.

31 International Council for the Exploration of the Sea, International Federation of Red Cross \& Red Crescent Societies, International Union for the Conservation of Nature, Nordic Council of Ministers, Nordic Environment Finance Corporation, North Atlantic Marine Mammal Commission, ospar Commission, Standing Committee of the Parliamentarians of the Arctic Region, United Nations Economic Commission for Europe, United Nations Development Program, United Nations Environment Program, World Meteorological Organization, and West Nordic Council.

32 Advisory Committee on Protection of the Seas, Arctic Institute of North America, Association of World Reindeer Herders, Circumpolar Conservation Union, International Arctic Science Committee, International Arctic Social Sciences Association, International Union for Circumpolar Health, International Work Group for Indigenous Affairs, National Geographic Society, Northern Forum, Oceana University of the Arctic, and World Wide Fund for Nature-Global Arctic Program.

33 Yareth Rosen, 'How Many Observers Can Arctic Council Handle?' The Independent Barents Observer (Fairbanks, AK, 16 March 2016) <http://thebarentsobserver.com/arctic/2016/o3/ how-many-observers-can-arctic-council-handle> accessed 29 July 2016. 
observers in practice but has to apply every time it wants to attend. Since 2008, it has set its sights on trying to receive accreditation as a more permanent Observer to the Arctic Council and put its bid forward at the Kiruna Ministerial meeting in $2013 .{ }^{34}$ This can be understood as the EU's attempt to increase its prominence in Arctic geopolitics. ${ }^{35}$ But Arctic Council members have pointed to the EU seal regime and its insensitivity to indigenous hunters as a principal reason to block Eu's membership bid. Until recently, the Eu's Observer status has been vetoed by Canada as an explicit response to the seal hunt dispute (described below). ${ }^{36}$ In 2014, Canada dropped its opposition to the EU's application to the Arctic Council after striking a deal on implementing exemptions for indigenous peoples from the $\mathrm{EU}$ seal regime $^{37}$ and as part of its bilateral trade negotiation (Comprehensive and Economic Trade Agreement). ${ }^{38}$ Nonetheless, some Greenland representatives in Danish Parliament called for their government to veto the EU's bid for the Arctic Council if the EU did not do away with its seal regime banning the importation of sealskin, even with an indigenous exception. ${ }^{39}$ The Eu's membership was left off the agenda (along with other observer applications) at the 2015 Ministerial Meeting of the Arctic Council in Iqaluit, and only Switzeralnd was the only national government to win observer status at the 2019 Fairbanks Ministerial meeting, the EU will now have to wait at least until the next Ministerial meeting in 2017 in Finland.

34 European Commission, The European Union and the Arctic Region (11 November 2008) $\operatorname{com}(2008) 763$ final <eeas.europa.eu/arctic_region/docs/com_08_763_en.pdf> accessed 17 October 2016.

35 Andreas Østhagen, 'In or Out? The Symbolism of the EU's Arctic Council Bid' [2013] Arctic Institute <http://www.thearcticinstitute.org/in-or-out-symbolism-of-eus-arctic/> accessed 3 August 2016.

36 'Canada against EU entry to Arctic Council because of seal trade ban', Canadian Broadcasting Corporation News (29 April 2009) http://www.cbc.ca/news/canada/north/ canada-against-eu-entry-to-arctic-council-because-of-seal-trade-ban-1.806188> accessed 29 July 2016.

37 Duncan Depledge, 'The European Union in the Arctic' <http://www.worldpolicy.org/ blog/2015/o6/24/european-union-arctic > accessed 19 September 2016.

38 European Commission Press Release, 'Canada-EU Summit-A new era in Canada-EU relations: Declaration by the Prime Minister of Canada and the Presidents of the European Council and the European Commission' (26 September 2014) <http://europa .eu/rapid/press-release_STATEMENT-14-288_en.htm> accessed 24 October 2016.

39 Kevin McGwin, 'EU Seal Ban: A Seal of Disapproval' The Arctic Journal (Nuuk, 18 February 2015). Russia is blocking the EU on more geopolitical terms, see Duncan Depledge, 'The EU and the Arctic Council' (European Council on Foreign Affairs, 20 April 2015) $<$ http://www.ecfr.eu/article/commentary_the_eu_and_the_arctic_council3005 $>$ accessed 18 September 2016. 
The EU has some pan-Arctic institutional presence through its parliamentarians who are members of the Conference of Parliamentarians of the Arctic Region. The Conference views the Arctic Council as the primary forum for Arctic cooperation. The Standing Committee (which includes one EU parliamentarian amongst a total of 11 members) works to promote the work of the Arctic Council and participates in the meetings of the Arctic Council as an Observer.

The Us, because of its possession of Alaska, was invited to be a founding member of the Arctic Council. While the us was skeptical of the need for the Arctic Council it nonetheless joined at the Council's inception in 1996. But like the $\mathrm{EU}$, it now has significantly increased the political resources it puts towards participating in the Arctic Council, especially since it held the chairmanship from 2015 to $2017 \cdot^{40}$

4

The Us and Alaska

\subsection{Hunting Rights and Sovereignty}

In order to understand us Arctic presence and policy, one must understand the historical legal relationship between the us and Alaska. In Alaska, the meaning and delineation of sovereign power remains a live debate. In the past, like today, hunting rights have played a central role in territorial debates over Alaska. ${ }^{41}$ I provide brief historical context as to how sovereignty in Alaska is the product of constant negotiation and is in practice dispersed across an array of authorities. From within this context, I then discuss the legal regime governing marine mammal hunting and provisions made for indigenous hunting rights as it relates to seals.

In Alaska, sovereignty has been the means through which indigenous peoples and settler colonists have defined their relationship between each other, and negotiated authority and jurisdiction over land. Indigenous claims to sovereignty in Alaska today arise from assertions of the inherent powers of self-governing communities that have lived with particular lands from time immemorial. Indigenous communities first engaged with sovereignty as a

40 Diddy R.M. Hitchins, 'An Alaskan Perspective: The Relationship between the US and Canada in the Arctic' (2011) 66(4) International Journal 971.

41 Hiroo Nakajima, "The Monroe Doctrine and Russia: American Views of Czar Alexander I and Their Influence upon Early Russian-American Relations' (2007) 31(3) Diplomatic History 439; 'The North Pacific Sealing Convention' (1911) 5(4) American Journal of International Law 1025; Garrett Boyle, 'Mutiny against the MMPA: A Look at Alaska SB 6o' (2013) 30(2) Alaska Law Review 207. 
legal and political concept tied to notions of nationhood and the state in their encounter with European migrants. The us lays legal claim to Alaska, and by extension to the Arctic, through the colonial doctrine of discovery. ${ }^{42}$ It began when the Us purchased what is now the State of Alaska from Russia in 1867 through the Treaty of Cession. ${ }^{43}$ Article 3 of the treaty deemed the tribes to be uncivilized and granted the us Federal government the power to subject almost all aboriginal peoples in the area to us federal law. ${ }^{44}$ Thus, the treaty followed the logic that Russia was the initial discovering nation, and the Us became its successor to legal title of the land used and occupied by indigenous peoples. Indigenous tribes were enraged that no one sought their consent or even consulted with them. The Us Federal Government's legal claim was that indigenous tribes only retained the right to the use and occupancy of the land as if they were tenants; this conflicted with native understanding of their relationship to the land. ${ }^{45}$ As it stands today in us law, indigenous communities retain the sovereign power of self-government which cannot be extinguished; but Congress in effect passes laws that alters indigenous authority and jurisdiction. Herein lies the space where Alaska Natives negotiate with or resist against us Federal law to define their sovereign power. If we understand authority as the power over someone or something, and jurisdiction as the scope of said power, Congress and the us Federal Government significantly control the levers of indigenous sovereignty. ${ }^{46}$ While indigenous peoples as us citizens have some leverage with the executive and legislative branch of us government, like for any citizen, this is power is determined by how well people can organize themselves and exert collective will within the national system.

The us federal government has recognized 229 Alaska Native governments, but without specifically identified territory. The result is that questions over sovereign powers of authority and jurisdiction most often arise through conflicts over subsistence hunting. In fact, subsistence and self-government remains to be the most legally complex and politically heated issue in Alaska

42 Robert T. Anderson, 'Alaska Native Rights, Statehood, and Unfinished Business' (2007) 43(1) Tulsa Law Review 17.

43 Treaty Concerning the Cession of Russian Possessions in North America (30 March 1867) 15 Stat. 539, Ts No. 301.

44 The us considered Unangans to be 'civilized' Russian subjects, and ostensibly could choose Russian or American citizenship through the Treaty. In practice, the United States did not recognize the civil rights of Unangans until 1966, see Barbara Boyle Torrey and Agafon Krukoff, Slaves of the Harvest: The Story of the Pribilof Aleuts (Tanadgusix Corp 1978).

45 See Anderson, n. 42 above.

46 Benjamin W. Thompson, 'The De Facto Termination of Alaska Native Sovereignty: An Anomaly in an Era of Self-Determination' (1999) 24(2) American Indian Law Review 421. 
today. But this is not a new issue. Ever since 1867 , tribes in Alaska have been fighting for hunting, gathering, and land rights. ${ }^{47}$ The struggle was made more acute after the Second World War when Alaska native peoples, demanding more land rights from the us federal government, came up against non-native desires to take of advantage of the postwar economic boom. ${ }^{48}$ When Alaska became a state in 1959, the federal government deliberately avoided the issue. Instead, it authorized the newly created state to select 103.35 million acres of 'vacant, unappropriated, and unreserved' land as its own from federal public land (representing about $28 \%$ of Alaska's total land base); while at the same time it recognized but did not define native rights. ${ }^{49}$ The clash between Native tribes and the new State government was then over which lands were 'vacant, unappropriated, and unreserved' and which were lands necessary and part of Native subsistence use. ${ }^{50}$

Today, this conflict continues between Native governments and the State government over different understandings of hunting rights. Alaska's Constitution does not recognize indigenous rights as such or grant any preference for subsistence hunting. Moreover, the State of Alaska's Department of Fish and Game has had a bias in favor of sport fishing and hunting by urban non-natives. ${ }^{51}$ The us government did not address Native hunting rights until the passing of the 1971 Alaska Native Claims Settlement Act (ANCSA), which forms the basis of the modern relationship between tribes in Alaska and the us Federal government. ${ }^{52}$ The act fundamentally transformed indigenous relations with the us Federal government and significantly curtailed Native sovereign power. ${ }^{53}$ First, the ANCSA extinguished Aboriginal title claims based on prior conveyances, use and occupancy, right, or foreign law. ${ }^{54}$ This, however, was not an effort to permanently abolish Native rights; instead the ANCSA then redefined indigenous powers of self-determination. In lieu of title claims, all Alaska Natives alive on 18 December 1971 received the right to obtain stock

47 David S. Case and David A. Voluck, Alaska Natives and American Laws (3rd ed, University of Alaska Press 2012) 24-33.

48 Sophie Theriault and others, 'The Legal Protection of Subsistence: A Prerequisite of Food Security for the Inuit of Alaska' (2005) 22(1) Alaska Law Review 35.

49 Alaska Statehood Act, Pub. L. 85-508, 72 Stat. 339 (7 July 1958) sections 4, 6.

5o See Theriault and others, n. 48 above; Anderson, n. 42 above.

$51 \quad$ See Case and Voluck, n. 47 above, $293^{-294 .}$

52 Pub. L. No. $92-203,85$ Stat. 688 (1971) (codified as amended at 43 U.s.C. $§ ~ 1601-1629 h$ (2000)).

53 Dalee Sambo Dorough, 'Inuit of Alaska: Current Issues' in Natalia Loukacheva (ed), Polar Law Textbook (Nordic Council of Ministers 2010).

$54 \quad 43$ USC $§ 1603$. 
in one of the newly created thirteen regional corporations and in more than two hundred village corporations. The ANCSA conveyed approximately fortyfive million acres of land to the Alaska Native Corporations through fee title, along with a cash payment of almost $\$ 1$ billion. ${ }^{55}$ Thus, land in Alaska was and remains governed in part through Alaska Native corporations created by the ANCSA and in turn through Alaska state corporate law.

The ANCSA also extinguished 'any aboriginal hunting or fishing rights that may exist. 56 Then, us Congress requested that the Secretary of Interior and State of Alaska take positive measures to protect native hunting rights. This did not happen and the question of subsistence hunting was left unaddressed (along with other key issues such as federal services and Native government). While Native tribes retained their sovereign hunting rights, the meaning and definition of those rights remained a matter to be decided by tribes in their debates with the Federal government through Congress and disagreements with the Federal government through the courts.

The 1980 Alaska National Interest Lands Conservation Act (ANILCA) ${ }^{57}$ was an attempt to further settle Alaska Native hunting and fishing rights. It did this by granting exclusive access to hunting, gathering, and fishing to all rural residents. Thus, it did not create rights to Native peoples in law and left the issue to the fact that most rural residents are Native. In 1989, the Alaska Supreme Court found this provision to be unconstitutional since it made a distinction between rural and non-rural Alaskans. ${ }^{58}$ To date, distinct Native subsistence hunting rights are not granted in positive law as a rule and are only provided through exceptions to wildlife management statutes such as the 2000 Migratory Bird Treaty Act, the 1972 Marine Mammal Protection Act (MMPA), and the 1973 Endangered Species Act. ${ }^{59}$

\subsection{The Economy of Seal Hunting Rights and Indigenous Sovereignty}

In Alaska, seal hunting is at the intersection of three aspects of village economies: subsistence, government transfer, and the market economy. ${ }^{60}$ It also has a broader existential meaning in which seal hunting is how indigenous

\footnotetext{
55 Case and Voluck, n. 47 above, 35, 75, 79 .

$56 \quad 43$ USC $§ 1603(b)$.

57 Alaska National Interest Lands Conservation Act, Pub. L. No. 96-487, 94 Stat. 2371 (1980) (codified as amended at 16 U.s.c. $\S \S 3101-3233$. (2000)).

$58 \quad$ McDowell $v$ State, 785 P.2d 1 (Alaska 1989).

59 Theriault and others, n. 48 above.

6o Lee Huskey, 'Alaska's Village Economies' (2004) 24(3) Journal of Land Resources \& Environmental Law 435.
} 
groups in the Arctic socially and culturally define themselves. In other words, seal hunting in the Arctic is a practice that is embedded within several economies - and those economies are conjoined through indigenous understandings and expressions of sovereign power and rights of self-determination. Indigenous groups make choices through this matrix to determine what seal hunting means and how it should be valued, and often those choices are conditioned by law.

us law grants Indigenous peoples in Alaska seal hunting rights as an exception to the MMPA. US Congress first enacted this on 21 October $1972 .{ }^{61}$ It prohibited us citizens on the high seas from harassing, hunting, capturing, or killing ('taking') protected species or anyone doing the same in us waters. It also prohibited importation of marine mammals and marine mammal products into the us. ${ }^{62}$ To some degree, us Congress passed the MMPA as a response to a public animal cruelty campaign against the hunting of harp seal pups in Canada, and general concerns about other marine mammals. ${ }^{63}$ Like the current EU seal regime, it was not specifically a response to species that were endangered. Native groups, in order to exercise their hunting rights, had to seek permission from the appropriate Federal Secretary. ${ }^{64}$

In 1994, the MMPA was significantly amended marking a shift in conservation policy from hunting moratorium to wildlife management. It also provided Native peoples more opportunities to define their hunting rights and be part of that management. ${ }^{65}$ As usual in the case when rights are granted, this did not resolve anything and instead signaled the beginning of a long, costly, and complex negotiation and contest between different federal and state agencies, sovereign tribes, and non-native hunters. ${ }^{66}$ What follows is an examination of how the law configured the political, social, economic, and social attributes of hunting (and the concomitant debates) in a particular way.

The MMPA operates within a convoluted system of government management. After the 1989 Alaska Supreme Court ruling, 'the federal government took over the management of fish and wildlife for subsistence purposes on

\footnotetext{
$61 \quad 16$ USC $\S \S 1361-1423 \mathrm{~h}(2000)$.

6216 USC $\S 1371(\mathrm{a})$.

63 H.R. REP. No. 707, 92d Cong., 2d Sess. (1971), reprinted in 1972 USCCAN 4144.

64 Other exceptions include taking for the purpose of scientific, commercial, and ecological activities.

65 Susan C. Alker, 'The Marine Mammal Protection Act: Refocusing the Approach to Conservation' (1996) 44(2) UCLA Law Review 527.

66 Kate Wynne, 'The Marine Mammal Protection Act: An Overview of Recent Changes' Alaska's Marine Resources (Fairbanks, September 1995) <http://nsgd.gso.uri.edu/aku/ akug95003.pdf > accessed 17 October 2016. For the initial implementation process, $\$ 2.5$ million were authorized to set up the new system but were not released immediately.
} 
Alaska public lands in 1990 (approximately $60 \%$ of Alaska lands), leaving the state to manage the remaining $40 \%$ of Alaska lands, including Native lands. ${ }^{\prime} 7$ The result is that hunting rights are governed by multiple legal regimes through a federal and state management system that is 'complicated and sometimes conflicting. 68

In sum, hunting rights to date are entangled in three, uneasy bundles of sovereign power: Native-Us Federal relations, Native-State of Alaska relations, and the constitutional division of power between the Federal and State government. Since tribes in Alaska are within the fold of us imperial adventures, us executive power and local tribes negotiate and contest the meaning, limits, and extent of sovereign power through us administrative law and not international law. ${ }^{69}$ It is helpful to understand the administrative structure before turning to the actual legislation.

The amended MMPA provides a structure to implement the Alaska Native hunting right exception, authorizing (but not requiring) the us Federal government to develop a co-management system with Alaska Native organizations. ${ }^{70}$ In 1997, the Indigenous People's Council for Marine Mammals (a coalition of Tribal marine mammal commissions/councils and other Native organizations in Alaska), U.s. Geological Survey Biological Resource Division (which falls under the auspices of the Department of Interior), Fish and Wildlife Service (Department of Interior), and National Oceanic and Atmospheric Administration (NOAA Fisheries is under the auspices of the Department of Commerce) developed a Memorandum of Agreement to provide the foundation and direction for the use of co-management funds provided under the MMPA. ${ }^{71}$ The result has been a number of place-specific or animal-specific

67 Alaska Federation of Natives, 2016 State Priorities <www.nativefederation.org/wpcontent/uploads/2016/02/2016statepriorities-2.5.2016.pdf> accessed 17 October 2016.

68 Ibid.; Case and Voluck, n. 47 above, 265; Jordan Diamond, Greta Swanson and Kathryn Mengerink, 'Rights and Roles: Alaska Natives and Ocean and Coastal Subsistence Resources' (2012) 8(2) Florida A\&M University Law Review 219.

69 There is, however, a strong argument made in the us that international law is increasingly becoming the platform from which Alaska Natives, and all indigenous groups in the Us, to assert their rights in relation to the us government, see Dorough, n. 53 above; Case and Voluck, n. 47 above, $1-20$.

$70 \quad 16$ USC $\S 1388$.

71 Memorandum of Agreement for Negotiation of Marine Mammal Protect Act Section 119 Agreements (August 1997) <https://alaskafisheries.noaa.gov/sites/default/files/ umbrellaagr97.pdf> accessed 17 October 2016; this was updated with Memorandum of Agreement for Negotiation of Marine Mammal Protect Act Section 119 Agreements (October 2006) <https://alaskafisheries.noaa.gov/sites/default/files/umbrellaagro6.pdf> accessed 17 October 2016. 
cooperative agreements and concomitant agencies. ${ }^{72}$ The result is a complex system of shared responsibility in which each commission or committee is a place of back-and-forth discussion between the Us Federal government and Native tribal councils- the theory being that these are 'government-togovernment' negotiations and neither has principal control over decisionmaking. The meaning and effect of co-management is not only a matter of administrative design but also arises through implementation. For example, State troopers will sometimes not cite someone for a violation and leave the matter to the appropriate tribal council. In sum, co-management can be understood as the complex, pluralist legal regime through which questions of authority and jurisdiction over hunting are decided both through agreement, implementation, and interpretation. ${ }^{73}$

The us government in many respects defines Native rights, but Alaska Natives assert those rights as a matter sovereign power because of pre-colonial contact history. The MMPA defines Alaska Native organization to mean a group designated by or formed through us law, which represents or consists of Indians, Aleuts, or Eskimos residing in Alaska. Thus, tribes retain inherent sovereignty but derive their standing in government-to-government negotiations from the us itself; they may, for example, obtain official designation as an Alaska Native Tribe, authorization through a co-management bodies, or legal personality through incorporation. An Alaska Native, as a us citizen, may also assert her Native rights by suing the appropriate federal or state agency in court, thus granting the final word on hunting rights to the us judiciary. ${ }^{74}$

The us government expresses its sovereignty through two agencies which have different jurisdiction, each of which negotiates with Alaska Native organizations. The Secretary of Commerce (through NOAA Fisheries) has jurisdiction over mammals that are members of the order of Cetacea and members of the order Pinnipedia (other than walruses). The Secretary of the Interior (through the Us Fish and Wildlife Service) has jurisdiction over all other marine mammals. ${ }^{75}$ Because each agency operates out of its own Federal

72 Alaska Beluga Whale Committee, Alaska Eskimo Whaling Commission, Aleut Marine Mammal Commission, Alaska Native Harbor Seal Commission, Cook Inlet Marine Mammal Council (disbanded in 2012), Ice Seal Committee, Traditional Council of St. George Island, and Tribal Government of St. Paul.

73 Eric Smith, 'Some Thoughts on Comanagement' (1996) 4(1) Hastings West-Northwest Journal of Environmental Law and Policy 1.

74 See for e.g. John v. United States, 247 F.3d 1032 (9th Cir. 2001).

7516 USC $\S 1362(12)(A)$. In fact, the legislation grants NOAA the jurisdiction and grants the power to whatever Secretary of the department in which NOAA is operating. 
department, they each operate within a distinct institutional history, has a different Secretary with her or his own particular agenda, and must respond to different political pressures. As a result, each agency enforces the law in its own way.

The us seal regime's laws are just as complex as its administrative structure. Through the MMPA, Congress first delimits indigenous hunting rights in Alaska in terms of ethno-cultural membership and geography. It does this by designating and defining the category of 'Alaska Native' and only granting hunting rights to 'any Indian, Aleut, or Eskimo who resides in Alaska and who dwells on the coast of the North Pacific Ocean or the Arctic Ocean'. Then, Congress grants anyone who meets these defined identities the right to take any marine mammal if the taking meets the following criteria:

(1) is for subsistence purposes; or

(2) is done for purposes of creating and selling authentic native articles of handicrafts and clothing ...; and

(3) in each case, is not accomplished in a wasteful manner. ${ }^{76}$

Last, the Us Federal government retains final authority to restrict or revoke this hunting right if the appropriate Secretary determines 'any species or stock of marine mammal subject to taking by Indians, Aleuts, or Eskimos to be depleted. ${ }^{77}$ In other words, the Secretary retains a conservation trump card against Alaska Natives.

Each one these points have been legally contentious. First, on the question of who is allowed to hunt and the category of 'Alaska Native': unlike the Alaskan Constitution, the MMPA singles out Alaska Natives and in doing so recognizes indigenous sovereignty to some degree. What makes the issue more antagonistic amongst people in Alaska is the fact that hunting rights are now embroiled in a constitutional debate that was triggered when the Alaska Supreme Court ruled in 1989 that ANILCA's provision privileging rural-and mostly Native-residents was unconstitutional because it contravened the 'equal access' clause of the Alaska Constitution. ${ }^{78}$ Native and pro-Native groups argue that the Alaska Constitution should be amended to bring it into compliance with ANILCA; while non-native groups argue that ANILCA

\footnotetext{
$76 \quad 16$ USC $\$ 1371(\mathrm{~b})$.

77 Ibid.

78 McDowell v. State, 785 P.2d 1, 9 (Alaska 1989).
} 
should be amended to bring it into compliance with the Alaska Constitution. ${ }^{79}$ Additionally, some conservationists oppose the government granting Native tribes subsistence rights because they worry that such rights will 'open the door' to commercial hunting. ${ }^{80}$ From another perspective, if an Alaska Native no longer 'dwells on the coast of the North Pacific Ocean or the Arctic Ocean', moving for example to an urban center like Fairbanks in the interior of the State, this suggests that she or he will likely lose their hunting rights.

Next, hunting practice criteria are also a matter of significant disagreement: hunting must be for the purpose of subsistence or making authentic handicrafts/clothing, and is not wasteful. To start with the overarching requirement of non-wastefulness, the criticism has been that 'interpretation has been ambiguous, and enforcement arbitrary', and such debates have eroded the relationship between indigenous hunters and government managers. ${ }^{81}$

ANILCA identifies the elements to subsistence, requiring Alaska Natives to show the hunt is a matter of economic and physical reliance, cultural or social value, and custom and tradition. ${ }^{82}$ Not only are there legal debates over the meaning of subsistence, but there are also socio-economic questions as to whether subsistence hunting should be treated more like a commercial commodity or as a communal right for Alaska villages. ${ }^{83}$ The more acute problem,

79 Alaska Federation of Natives, 2016 State Priorities <www.nativefederation.org/wpcontent/uploads/2016/o2/2016statepriorities-2.5.2016.pdf > accessed 17 October 2016; Jack B. McGee, 'Subsistence Hunting and Fishing in Alaska: Does ANILCA's Rural Subsistence Priority Really Conflict with the Alaska Constitution?' (2010) 27(2) Alaska Law Review 221.

8o Alma Soongi Beck, 'The Makah's Decision to Reinstate Whaling: When Conservationists Clash with Native Americans over and Ancient Hunting Tradition' (1996) 11(2) Journal of Environmental Law \& Litigation 359, 362.

81 Martin Robards and Julie Lurman Joly, 'Interpretation of Wasteful Manner within the Marine Mammal Protection Act and Its Role in Management of the Pacific Walrus' (2007) 13(2) Ocean \& Coastal Law Journal 171.

8216 USC $\S 3113$. See also Jennifer L. Tomsen, 'Traditional Resource Uses and Activities: Articulating Values and Examining Conflicts in Alaska' (2002) 19(1) Alaska Law Review 167; Case and Voluck, n. 47 above, 266-267. The Katie Johns litigation remains one the most politically contentious, legally complicated, and popularly (in)famous series of cases on federal, tribal and state interests over jurisdiction of Alaska Native subsistence rights, John v. United States, 247 F.3d 1032 (9th Cir. 2001). See Heather R. Kendall-Miller 'Katie John-Her Life and Legacy' (Native American Rights Fund) <www.narf.org/cases/ katie-john-v-norton/> 17 October 2016.

83 Jeremy David Sacks, 'Culture, Cash or Calories: Interpreting Alaska Native Subsistence Rights' (1995) 12(2) Alaska Law Review 247; William M. Bryner, 'Toward a Group Rights Theory for Remedying Harm to the Subsistence Culture of Alaska Natives' (1995) 12(2) Alaska Law Review 293. 
however, is the sovereign power question of who gets to decide what is subsistence hunting. In the division of power in Alaska, the State authority and legal regime is often rigid and backward looking, while the Federal system of co-management with tribes tends to be more accommodating and responsive to indigenous claims. ${ }^{84}$ Nonetheless, Federal conservationist legislation that carves out indigenous exception such as the MMPA do not grant tribes a mandatory role in the federal government's decision-making on whether and how much to limit subsistence hunting. Moreover, the Federal government makes these decisions through executive orders, which does not provide tribes with clarity since these orders are more easily made and unmade than legislation (the corollary is that they are more negotiable). More problematic is the fact that each federal agency has their own concept of when or how they engage in co-management consultations. ${ }^{85}$

The requirement that hunting be for the purpose of making 'authentic' handicraft or clothes, the other criteria for allowable indigenous hunting, is vexing. One Federal agency (Fish and Wildlife Service) decided to only look to the past and limit 'authentic' articles to those 'commonly produced' before the enactment of the MMPA (in this case it was products made from sea otter skin). The Federal Court of Appeal struck down their legislation and held that legislation sufficiently defined authentic native handicrafts as being 'made at least in part of "natural materials", and ... [produced] ... in traditional native ways, such as weaving, carving, and stitching.' Thus, the court held that the agency had no discretion to impose what it deemed to be as additional requirements. ${ }^{86}$

The final way that Congress delineates its authority over hunting rights is through wildlife protection powers. While seals are not currently endangered, this may change as the climate rapidly changes raising the issue of seal protection in the future. Alaska Natives' rights are respected, however, by the fact that the Federal Government are accountable to them (and the courts) a very specific burden of proof showing 'substantial evidence on the basis of the record as a whole' that a species or stock of marine mammal is depleted. ${ }^{87}$ The us Federal government rarely exercises this authority, but when it does the political stakes are high. This is exemplified in the case when the Federal government banned all gray whale hunting on conservation grounds contra their treaty with the Makah tribe in the Northern Pacific (in the State of Washington); the

84 See Theriault and others, n. 48 above; Diamond, Swanson and Mengerink, n. 68 above.

85 Elizaveta Barrett Ristroph, 'Alaska Tribes' Melting Subsistence Rights' (2010) 1(1) Arizona Journal of Environmental Law \& Policy 47, 71-72.

86 Didrickson $v$ United States Department of the Interior, 982 F.2d 1332 (9th Cir. 1992).

$87 \quad 16$ USC $§ 1371(b)(3)$. 
Tribe forcefully responded through a long legal battle and extra-administrative measures. ${ }^{88}$

The reality of everyday life is that communities' cultural, economic, and social practices and ensuing meanings are always responding to changing conditions. ${ }^{89}$ Subsistence hunting, like all community practices, is embedded in the past but also alive in the present. Thus, as indigenous communities change so does their sense of subsistence hunting's meaning and purpose. What is consistent is that subsistence hunting remains central to indigenous self-understanding in Alaska.

The legal complexity of the seal regime in Alaska is the result of that fact ever since statehood in 1959 sovereignty remains-in the words of a doyen of indigenous law in the US - a matter of 'unfinished business' in Alaska. ${ }^{90}$ And as long as it remains a matter of 'unfinished business' the Us's claims to sovereignty in the Arctic will be politically tenuous.

In 2009, the EU enacted regulations whose aim was to ban the importation of seal products into its market. ${ }^{91}$ It made exceptions for indigenous communities, marine resource management, and personal use by travelers. The indigenous community exception only allowed seal products that result from Inuit or other indigenous communities if they met the following criteria:

(a) seal hunts conducted by Inuit or other indigenous communities which have a tradition of seal hunting in the community and in the geographical region;

88 See Beck, n. 80 above; Paul Gottleib, 'U.S. Halts Makah Whaling Study After Seven Years Over "New Scientific Information"' (Peninsula Daily News, 23 May 2012) <www.peninsuladailynews.com/article/20120523/NEWS/305239987> accessed 13 July 2016.

89 Chanda L. Meek, 'Comparing Marine Mammal Co-Management Regimes in Alaska:Three Aspects of Institutional Performance' (Doctoral Dissertation, University of Alaska 2009) <http://www.uaf.edu/files/rap/Meek\%2odissertation\%2009.pdf> accessed 2 August 2016; Ristroph, n. 85 above.

90 See Anderson, n. 42 above.

91 Parliament and Council Regulation (EC) 1007/2009 on trade in seal products, [2009] OJ L286/36 (Basic Regulation). The exceptions are contained in Commission Regulation (EU) No. 737/2010 laying down detailed rules for implementation of Regulation (EC) No. 1007/2009 of the European Parliament and of the Council on trade in seal products, [2010] oJ L216/1 [Implementing Regulation]. 
(b) seal hunts the products of which are at least partly used, consumed or processed within the communities according to their traditions;

(c) seal hunts which contribute to the subsistence of the community. ${ }^{92}$

This seal ban created an international maelstrom including a series of cases before the EU courts and WTO. I first provide a summary of these cases as part of the larger political context surrounding the $2009 \mathrm{EU}$ seal regime since the current 2015 seal regime was drafted in response to these cases. Using the sovereignty analytic developed in the previous section on Alaska, I then examine the process that led to the current seal regime and the text of the regime itself.

\subsection{Seal Ban Cases}

Inuit groups in Canada were frustrated that they had no practical way to take advantage of the indigenous community exception because the EU did not create any administrative structure to clarify and enforce the measure in a way that applied to them. As exemplified in Alaska, the terms of the measure were not self-explanatory and also required significant administrative structure in order to be effective. The EU did put into place a mechanism that allowed (the mostly Inuit) Greenlandic hunters to benefit from the exception. ${ }^{93}$ Nonetheless, Inuit groups in Canada and Greenland came together in their broader concern that even with an indigenous exception, such legislation would cause the entire seal market to collapse. In alliance with all seal hunters they called for an end to the whole seal regime.

This position was partly based on experience: international animal welfare activists had successfully led anti-seal hunt campaigns in the 1970s and 1980s that caused the us to ban the importation of all seal products in 1972 and the EU to ban the importation of the white pelts of the youngest pups in $1983 .{ }^{94}$ This in effect reduced the price of seal pelts and significantly diminished all seal hunting. The Inuit position was also based on contemporary economic conditions: by the European Commission's estimate, $30 \%$ of global trade in seals is within the EU market. ${ }^{95}$ The EU's ban would likely cause surplus seal products to flood other markets thereby depressing the global price. Moreover,

\footnotetext{
92 Implementation Regulation, article 3.

93 See Chapter 4. in verify asinstruction in correction.

94 Peter L. Fitzgerald, "Morality" May Not Be Enough to Justify the EU Seal Products Ban: Animal Welfare Meets International Trade Law' (2011) 14(2) Journal of International Wildlife Law \& Policy 85 .

95 European Commission, 'Proposal for a Regulation of the European Parliament and of the Council concerning Trade in Seal Products', сом (2008) 469 final.
} 
Inuit hunters and their communities' livelihood would be affected since not all seal products they produced would satisfy the specific, exceptional conditions laid out in the EU regulation. Even if the products did meet the regulatory exception, Inuit traders would have to bear the administrative and financial burden proving the hunt and product meet $\mathrm{EU}$ criteria, thereby raising the cost of production. Moreover, Inuit access to the international seal product markets depends upon the marketing channels created and maintained by the much larger Atlantic seal hunt. The ban would do away with these channels, which would in effect deny Inuit hunters market access. ${ }^{96}$

Inuit were also angry that animal welfare activists, celebrities, and the regime itself characterized seal hunting as a cruel and barbaric practice. They were frustrated that animal welfare activists and EU officials did not understand the reality of the seal hunts, conditions in the Arctic, or the centrality of seal hunting in almost all aspects of Inuit life. This had economic implications for even if Inuit seal products made it to the European market, they would be tainted by demonizing moralistic language. Moreover, Inuit heard this complaint as patronizing especially since their identity was at stake. For example, at the 2014 Oscars, comedian Ellen DeGeneres raised funds by posting a selfie photo and sent about $\$ 1.5$ million to the Humane Society, which strongly opposes the seal hunt. In response, Killaq Enuaraq-Strauss, a 17-yearold Inuk woman from Iqualuit and Degeneres fan, posted a video, where she told Degeneres in the most considered and considerate way, 'We do not hunt seals ... for fashion. We hunt to survive. ${ }^{97}$ This triggered an online campaign and Inuit flooded Twitter with selfies posing with seal fur and affirming the importance of hunting seal for food, clothing, and traditional reasons (\#sealfies).

Like the Inuit, some commentators questioned the exception's legitimacy or effectiveness and predicted that the seal regime would shut down all seal trade and hunts, commercial or otherwise. Some found that the EU seal regime contravened indigenous human rights since it potentially threatened Inuit livelihood and way of life. ${ }^{98}$ Others focused on the incoherence of the

96 Tamara Perišin, 'Is the EU Seal Products Regulation a Sealed Deal? EU and WTO Challenges' (2013) 62(2) International and Comparative Law Quarterly 373; Elizabeth Whitsitt and Nigel Bankes, 'The WTO Panel Decision on the EU's Rules on the Marketing of Seal Products: Who Won and Who Lost?' (ABlawg, 1o January 2014) <http://ablawg .ca/2014/01/10/the-wto-panel-decision-on-the-eus-rules-on-the-marketing-of-seal-productswho-won-and-who-lost/> accessed 29 September 2016.

Killaq Enuaraq-Strauss, 'Dear Ellen' (YouTube, 23 March 2014) <https://www.youtube .com/watch?v=eRPEz57_l_M> accessed 24 October 2016.

98 Dorothée Cambou, 'The Impact of the Ban on Seal Products on the Rights of Indigenous Peoples: A European Issue' (2013) 5 Yearbook of Polar Law 389; Kamrul Hossain, 'The EU 
legislation pointing out that it served multiple conflicting purposes namely the protection of animal welfare concerns, the need to harmonize a fragmented internal market, and an attempt to protect indigenous rights. ${ }^{99}$ The Court of Justice of the European Union (CJEU) upheld the Regulations on the basis of Article 95 of the EC Treaty and determined that the principal objective of the EU's Sealing Regulations '... is not to safeguard the welfare of animals but to improve the functioning of the internal market.'100 The wто Panel found that that hunting methods used by indigenous hunters '... can cause the very pain and suffering for seals that the EU public is concerned about' and as such the indigenous community exception bore no rational connection to the EU's alleged concern for animal welfare. ${ }^{101}$ One Member of the European Parliament (MEP) agreed that the legislation did not clearly serve animal welfare purposes and stated,

[t]here is something not strictly rational about singling out seals for special treatment. They are not an endangered species-even the WWF says so. We do not get anything like the clamour about hunting seals on behalf of wasps or woodlice or wolverines or worms. Then again, democracy is not strictly rational. ${ }^{102}$

Others have pointed out that not only did the European and wTо courts have ample evidence that seals did not necessarily suffer in the hunts, but that the EU legislation was disconnected from scientific and social reality of seal hunting communities. ${ }^{103}$ The EU's position that the legislation's purpose was to

Ban on the Import of Seal Products and the WTO Regulations: Neglected Human Rights of the Arctic Indigenous Peoples?' (2013) 49(2) Polar Record 154.

See Fitzgerald, n. 94 above; Whitsitt and Bankes, n. 96 above; Nikolas Sellheim, 'The Goals of the EU Seal Products Trade Regulation: From Effectiveness to Consequence' (2015) 51(3) Polar Record 274.

100 Case T-526/10 Inuit Tapiriit Kanatami and Others $v$ Commission (General Court, 25 April 2013), paras 35, 83 .

101 WTO, European Communities-Measures Prohibiting the Importation and Marketing of Seal Products-Reports of the Panel (25 November 2013) WT/DS400/R and wT/DS401/R, para. 7.275.

102 Quoted in Fitzgerald, n. 94 above, 129.

103 Nikolas Sellheim, 'The Right Not to Be Indigenous: Seal Utilization in Newfoundland' (2014) Arctic Yearbook 546; Nikolas Sellheim, "Direct and Individual Concern" for Newfoundland's Sealing Industry?-When a Legal Concept and Empirical Data Collide' (2015) 6 Yearbook of Polar Law 466; Nikolas Sellheim, "The Narrated "Other" -Challenging Inuit Sustainability Through the European Discourse on the Seal Hunt' in Kamrul Hossain and Anna Petrétei (eds), Understanding the Many Faces of Human Security (Brill 2016). 
protect animal welfare was not strengthened since it defended the seal regime at the WTO as a measure necessary to protect public morals ${ }^{104}$ and not in terms of exceptional provisions in the GATT that allowed states to restrict trade if it was necessary to protect animal life and health. ${ }^{105}$

One reason that the issue bubbled up onto international politics was because the price of seal pelts doubled from 2001 to 2004 due to a thriving seal population and new markets in Russia, Ukraine, Poland, and China. Inuit hunters and struggling communities in Newfoundland were excited about the prospect of revived market. ${ }^{106}$ With the new booming market, animal activists reinvigorated their international campaign against seal hunting. Moreover, animal activists were empowered by 2009 Treaty on the Functioning of the European Union which placed a legal obligation on the EU and Member States to 'pay full regard to welfare requirements of animals' when enacting and enforcing EU policies. ${ }^{107}$

Inuit groups quickly mobilized against the $2009 \mathrm{EU}$ seal regime. In April 2009, the Nunavut Premier Eva Aariak asked the Federal Government of Canada to oppose the Eu's bid to seek Observer Status at the Arctic Council. The Federal Government accommodated this request, which was a political blow to the EU trying to position itself as an Arctic power-the EU seal regime was now one of the major issues in Arctic politics. Meanwhile, both the Governments of Nunavut and Canada mounted a campaign to convince EU parliamentarians to vote against the legislation. ${ }^{108}$

When that failed, Inuit Tapiriit Kanatami (representing Inuit interests in Canada) lead advocacy groups from Canada and Greenland, associations of hunters from Canada and Greenland, individual Inuit hunters, and other representatives from the seal hunting industry from Canada, Greece, and Norway in a series of suits in EU courts. The General Court found the challenge inadmissible primarily on the grounds that the measure in question was a legislative

104 General Agreement on Tariffs and Trade (14 April 1994) (GATT) 1867 UNTS 187, 33 ILM 1153 (1994), article $\mathrm{xx}(\mathrm{a})$.

105 GATT, article $\mathrm{XX}(\mathrm{b})$.

106 Clifford Kraus, 'New Demand Drives Canada's Baby Seal Hunt' New York Times (New York City, 5 April 2004), <http://www.nytimes.com/2004/04/05/world/new-demand-drivescanada-s-baby-seal-hunt.html?_r=0 > accessed 24 October 2016.

107 Article 13, Treaty on the Functioning of the European Union (TFEU) [2012] OJ C326/47.

108 'Canada against EU entry to Arctic Council because of seal trade ban' ( $\angle B C$ News, 29 April 2009) <http://www.cbc.ca/news/canada/north/canada-against-eu-entry-to-arctic-councilbecause-of-seal-trade-ban-1.806188> accessed 24 October 2016. 
and not regulatory measure. ${ }^{109}$ The Court of Justice of the European Union (CJEU) upheld this finding on appeal. ${ }^{110}$

Inuit Tapiriit Kanatami then lead the group to challenge the implementing measure before the European courts. This time the courts did not address the admissibility question and instead focused on the substance of the legal claims. The General Court of the CJEU dismissed the applicants claims that: 1) the Commission did not have the appropriate legal basis to enact the regulation and;2) that regulation breached proportionality and subsidiary rights, and fundamental rights. ${ }^{111}$ The applicants lost their appeal before the CJEU. ${ }^{112}$ Part of the applicants' argument was that General Court erred in finding not applying Article 19 of the United Nations Declaration on the Rights of Indigenous Peoples, especially since the Declaration was mentioned in the Recital of the measure. Article 19 provides that 'States shall consult and cooperate in good faith with the indigenous peoples concerned through their own representative institutions in order to obtain their free, prior and informed consent before adopting and implementing legislative or administrative measures that may affect them.' The CJEU held that the Declaration was not binding and the reference to it in the Recital only provided reasoning for the indigenous exception and did not acknowledge a legal obligation - which in effect denied Inuit rights to self-determination within the EU.

While the Eu court cases proceeded, Canada and Norway challenged the EU seal regime before the WTO. ${ }^{113}$ Their claims were that the regime was discriminatory and contravened 'Most Favored Nation' and 'National Treatment' obligations under the General Agreement on Tariffs and Trade (GATT) and

109 Case T-18/10 Inuit Tapiriit Kanatami and Others $v$ Commission (General Court, 6 September 2011) ECR 11-5599; Article 263, TFEU: '[a]ny natural or legal person may ... institute proceedings against an act addressed to that person or which is of direct and individual concern to them, and against a regulatory of direct concern to them and does not entail implementing measures.'

110 Case C-583/11 P Inuit Tapiriit Kanatami and Others $v$ Commission (Grand Chamber, 3 October 2013).

111 Case T-526/10 Inuit Tapirit Kanatami and Others $v$ Commission (CJEU, 25 April 2013).

112 Case C-398/13 P Inuit Tapiriit Kanatami and Others $v$ Commission (CJEU, 3 September 2015).

113 wто, European Communities - Measures Prohibiting the Importation and Marketing of Seal Products-Reports of the Panel (25 November 2013) wT/DS40o/R and wT/DS401/R; wTо, European Communities-Measures Prohibiting the Importation and Marketing of Seal Products - Reports of the Appellate Body (22 May 2014) (WTO AB Seals) AB-2014-1 and AB-2014-2. 
Technical Barriers to Trade Agreement (твт). They also claimed that regime violated the твт because it was not 'necessary to achieve a legitimate objective' and constituted an 'unnecessary obstacle to trade'. Much like the CJEU, the wTo Appellate Body (AB) held that the EU Seal regime was not a 'technical regulation' and therefore the твт did not apply.

The AB did hold that EU seal regime contravened GaTT Article I: (MostFavored Nation) because it unjustifiably discriminated against all seal products from Canada and Norway in favor of seal products from Greenland. It followed, however, with the conclusion that the EU could provisionally justify its ban as a general exception under GATT Article $\mathrm{XX}(\mathrm{a})$ as a measure necessary to protect public morals. The AB's conclusion was provisional because the $\mathrm{AB}$ also found that the EU seal regime favored Greenlandic Inuit hunters over Canadian Inuit hunters because the EU did not pursue 'cooperative arrangements to facilitate the access of Canadian Inuit to the [indigenous community] exception'; the AB held that as a result the EU had not shown that their ban was not arbitrary or unjustifiable suggesting that if the EU treated all indigenous hunters equally it would be wTo compliant. ${ }^{114}$

\subsection{The Process Leading to the New Seal Regime}

Inuit leaders throughout the whole fight against the EU through the courts did not assert their hunting rights in explicit terms of sovereignty and instead framed the issue as a matter of human rights, wTо law, and Eu law. Nonetheless, after the series of cases were decided, one can see how sovereignty-understood as the authority to decide what rules applied to seal hunting - was in practice negotiated and contested amongst national and transnational Inuit advocacy groups, the Government of Canada, the Government of Nunavut, the WTO courts, the EU courts, the EU Parliament, EU Council, and EU Commission in the process of developing the new seal regime.

Several months after the wTо Ав report was released, all the relevant authorities and groups adjusted to the new legal landscape, politically regrouped, and mobilized. Canada and the EU ironed out their economic differences and negotiated a framework to ensure the indigenous exception would allow actual access for Inuit seal products into the product, while also finalizing the text of the Canada-EU bilateral trade agreement. ${ }^{115}$ In return,

\footnotetext{
114 Wто Ав Seals para. 5·337.

115 European Commission, 'On the Joint Statement by Canada and the European Union on Access to the European Union of Seal Products From Indigenous Communities of Canada' C(2014) 5881 final; 'Canada, EU strike deal on indigenous-hunted seal products:
} 
Canada agreed to support the Eu bid for Observer Status at the Arctic Council. Thus, the EU was able to preserve its ability to enact its seal regime and in effect govern seal hunts in the Arctic while also garnering more support for its position in the Arctic Council.

Indigenous groups were cautiously favorable with the prospect of an effective indigenous exception. But since details were still not worked out it was unclear whether the Inuit would have meaningful input in the process or whether the new seal regime would actually benefit indigenous people. Duane Smith, president at the time of ICC Canada statement captures the concern of how much power the EU may retain when he stated, 'Hopefully, [Canada and the $\mathrm{EU}]$ resolve this issue so that we don't have to deal with this every time the EU has elections.'116

The European Commission released its proposal for a new seal regime on 6 February 2015. ${ }^{117}$ Inuit hunting advocacy groups, such as Inuit Sila from Greenland took a two-pronged approach. They continued to outright oppose the seal import ban. But seeing that the process was continuing, in the alternative they also argued that the EU had to make an active effort undoing the stigma against seal products and inform consumers that sealskin is sustainable and legal, and invest in businesses that help increase the sale of seal products. ${ }^{118}$ The EU Parliament took up some of those points and successfully fought the Council of the European Union and the European Commission to include a provision in the regime that requires the European Commission to inform the public as such. ${ }^{119}$ Parliamentarians also successfully added more language in

Joint statement gives Inuit seal products access to EU market; non-aboriginal sealers left on the floe edge' NunatsiaqOnline (Iqaluit, 13 October 2014) < http://www.nunatsiaqonline .ca/stories/article/65674canada_eu_strike_deal_on_indigenous-hunted_seal_products/> accessed 24 October 2016; Jim Bell, 'EU Trade Deal Good for Nunavut Fish Harvesters, Tootoo says', NunatsiaqOnline (Iqaluit, 29 April 2016) <http://www.nunatsiaqonline.ca/ stories/article/65674eu_trade_deal_good_for_nunavut_fish_harvesters_tootoo_says/> accessed 24 October 2016.

116 Chris Plecash, 'Seal Deal Clears Way for EU Observer Status at Arctic Council' Embassy (Ottawa, 22 October 2014) $1<$ http://www.nationalnewswatch.com/2014/10/22/seal-deal -clears-way-for-eu-observer-status-at-arctic-council/\#.WXEjRYqQxE4> accessed 20 July 2017.

117 European Commission, 'Proposal for a Regulation of the European Parliament and of the Council amending Regulation (EC) No 1007/2009 on trade in seal products' (Proposal for New Seal Regime) сом(2015) 45 final.

118 Kevin McGewin, 'Let Them Eat Brussel Sprouts' The Arctic Journal (Nuuk, 10 February 2015).

119 Article 5a, European Parliament and Council Regulation (EU) 2015/1775 amending Regulation (EC) No 1007/2009 on trade in seal products and repealing Commission Regulation (EU) No 737/2010 (Basic Regulation 2015) [2015] OJ L 262/1. 
an explicit effort to emphasize that hunting is a matter of self-determination. The Commissions proposal framed hunting rights in the following way:

seal hunting is an integral part of the socio-economy, nutrition, culture and identity of the Inuit and other indigenous communities, making a major contribution to their subsistence. ${ }^{120}$

Parliamentarians managed to add the statement that 'seal hunting was a major contribution to indigenous subsistence and development, providing food and income to support the life and sustainable livelihood of the community, preserving and continuing the traditional existence of the community.'121 Also, references to hunting as 'cruel' were removed and references to indigenous rights were placed more centrally as an effort to reduce the assumption in many people's mind that all seal hunting was inhumane.

After the release of the proposed new seal regime, the Governments of Greenland and Nunavut came together and released a joint statement emphasizing the role that seal hunting played in their way of life, sense of self, and human rights. ${ }^{122}$ They concluded by encouraging 'the $\mathrm{EU}$ to work with us in a manner that respects for our way of life and the United Nations Declaration on the Rights of Indigenous Peoples, to ensure all Indigenous peoples have equal access to, and benefits from, the implementation of the Indigenous Communities Exemption.' ${ }^{123}$ This communicated that the respective Inuit governments' tactic was to accept that the new EU seal regime was going forward and work to ensure that that Inuit rights of self-determination were as protected as much as possible within this new law.

120 Proposal for New Seal Regime, $\operatorname{coM}(2015) 45$.

121 Basic Regulation 2015, recital para. 2. Cristian-Silviu Bușoi, 'EU Seal Products Trade Rules Must Respect Inuit Culture' The Parliament Magazine (Brussels, 13 July 2015) <http:// www.theparliamentmagazine.eu/articles/opinion/eu-seal-products-trade-rules-mustrespect-inuit-culture $>$ accessed 24 October 2016.

122 The Government of Nunavut is a semi-autonomous body governing a mostly Inuit community. Because Nunavut is a Canadian territory, it is created through federal law (unlike provinces which are created by the Canadian Constitution). This means it theoretically has a more direct relationship with the Federal government than the provinces.

123 Government of Greenland, 'Joint Statement of the Governments of Greenland and Nunavut regarding the Revision of the EU Seal Ban Regulation' (24 April 2015) <http:// naalakkersuisut.gl/ /media/Nanoq/Files/Attached\%2oFiles/Udenrigsdirektoratet/Joint\% 2ostatement\%202015/240415_Joint\%2oStatement\%2oENG.pdf> accessed 24 October 2016. 
While the Eu Parliament was able to find some compromise with the Council and Commission on meeting Inuit demands for enhancing references to indigenous self-determination, the regime by the very act of its existence is in effect a co-management system in which the EU shares sovereign power with the Governments of Nunavut, Greenland, and Canada. The EU seal regime forces Arctic authorities to engage in 'government-to-government' negotiations over seal hunting with the $\mathrm{EU}$.

Under the new regime, the EU sets the rules and approves recognized bodies which implement the rules. The new criteria only focus on the hunting methods and do not scrutinize the seal products themselves. But, in order to comply with wTо law, due regard for animal welfare was now included as a determining factor. Now seal products from indigenous hunts will only be allowed into the EU market if they meet the following criteria:

(a) the hunt has traditionally been conducted by the community;

(b) the hunt is conducted for and contributes to the subsistence of the community, including in order to provide food and income to support life and sustainable livelihood, and is not conducted primarily for commercial reasons;

(c) the hunt is conducted in a manner which has due regard to animal welfare, taking into consideration the way of life of the community and the subsistence purpose of the hunt. ${ }^{124}$

To date, the EU has authorized the Governments of Greenland ${ }^{125}$ and Nunavut ${ }^{126}$ to implement the indigenous exception. Thus, Inuit governments retain some power in how the system is managed since they assess the

124 Article 1, Basic Regulation 2015.

125 European Commission, 'Decision Recognising the Greenland Department of Fisheries, Hunting and Agriculture (APNN) in accordance with Article 3 of Implementing Regulation (EU) 2015/1850 laying down detailed rules for the implementation of Regulation (EC) No 1007/2009 of the European Parliament and of the Council on trade in seal products' C (2015) 7274 final, <http://ec.europa.eu/environment/biodiversity/animal_welfare/seals/ pdf/C_2015_7274_en.pdf> accessed 24 October 2016.

126 European Commission, 'Decision recognising the Department of Environment, Government of Nunavut in accordance with Article 3 of Implementing Regulation (EU) 2015/1850 laying down detailed rules for the implementation of Regulation (EC) No1007/2009 of the European Parliament and of the Council on trade in seal products' C (2015) $7273<$ http://ec.europa.eu/environment/biodiversity/animal_welfare/seals/pdf/ C_2015_7273_en.pdf> accessed 24 October 2016. 
conditions of the hunt that generated the seal products according to the EU indigenous exception. Then (if appropriate), the respective authorized government agency issues the attesting document, which accompanies the seal product into the EU market. This document is what confirms the legality of the seal product and all subsequent invoices related to the product must contain a reference to the number of the attesting document. ${ }^{127}$ As we saw in Alaska, terms such as 'subsistence' and 'tradition' are complex, dynamic ideas best determined by the communities themselves.

Much like the Us Secretary of the Interior or Commerce in Alaska, EU authorities, however, retain the final word. Disputes over the authenticity or correctness of the attesting document are to be determined by each EU Member States. ${ }^{128}$ It is unclear what this means, and one can imagine Inuit hunters having to navigate an inconsistent, fragmented dispute resolution system. Moreover, in order to respond to the wTO ruling and the АB concerns about the seal regime being arbitrary and unjustified in its ability to distinguish between commercial and subsistence hunting, the new seal regime accords the Commission heightened powers to scrutinize indigenous hunters: if the Commission has evidence that indigenous hunts are 'commercial' it may prohibit the placing on the market or limit the quantity that may be placed on the market of seal products resulting from the hunt concerned. Thus, the Commission is the final arbiter of interpreting what is meant by 'subsistence' and what is 'commercial', what is 'traditional', and what constitutes appropriate consideration for animal welfare. From Alaska, we learned that this interpretive authority is a key power in governing seal hunts.

The language empowering the Commission to conduct 'appropriate consultations' is not clear as to whether this is mandatory or only permitted. Nor does it explain whether the Commission has to consider the input from experts and stakeholders when making its final decision. ${ }^{129}$ As a result, the standard of proof is unclear. Much like how each us Federal agency interprets its duty to consult Alaska Natives, Inuit seal hunters will have to see how the EU Commission will interpret its duty.

\footnotetext{
127 Basic Regulation 2015.

128 Article 4, Basic Regulation 2015.

129 Basic Regulation 2015, recital para. 5: 'It is of particular importance that the Commission carry out appropriate consultations during its preparatory work, including at expert level. It is also important that the Commission carry out appropriate consultations with the countries of origin concerned and with relevant stakeholders. The Commission, when preparing and drawing up delegated acts, should ensure a simultaneous, timely and appropriate transmission of relevant documents to the European Parliament and to the Council:
} 
The new seal regime forces the Governments of Canada, Nunavut, and Greenland to expend resources on implementing the new regime and responding to market conditions that they could have otherwise spent on other services for Inuit communities. For example, the Government of Canada allocated CAD 5.7 million over five years to build the Inuit seal industry and create the certification system for the EU market. ${ }^{130}$ The Government of Greenland spent large sums of money to counter negative public perception and promote and document the sustainability of the seal hunt. ${ }^{131}$

Even with all these provisions that distribute decision-making power across different authorities, the EU still retains significant power in affecting the seal product market. The seal products market has still not recovered from 2009 mainly due to public perception in the EU that all seal products are illegal or immoral. The market is at the mercy of how quickly the EU works with the respective authorities to get the new seal regime up and running. For example, Danish and Greenlandic MEPs have been frustrated with how slow the Commission has been in launching an awareness-raising campaign. In fact, the Commission has interpreted their duty to raise public awareness to be about 'informing the public and competent authorities in order to facilitate the implementation of the regulation and of its exceptions' and explicitly not as a strategy to 'restore consumer confidence.' ${ }^{132}$ This approach will undoubtedly limit the ability of seal product prices to rise.

While Inuit governments work hard to ensure that Inuit rights of selfdetermination are protected within the new system, Inuit hunter advocates are consolidating their efforts on a parallel tract and continue to challenge the legitimacy of the new seal regime itself. ${ }^{133}$

130 Jim Bell, 'Nunavut MP says $\$ 5.7 \mathrm{M}$ Sealing Fund is "Huge for Inuit"' NunatsiaqOnline (Iqaluit, 23 April 2015) <http://www.nunatsiaqonline.ca/stories/article/65674nunavut_ mp_says_5.7m_sealing_fund_is_huge_for_inuit/> accessed 24 October 2016; 'Federal Money Flowing to Nunavut to Certify, Promote Sealskin' NunatsiaqOnline (Iqaluit, 29 January 2016) <http://www.nunatsiaqonline.ca/stories/article/65674federal_money_ flowing_to_nunavut_to_certify_promote_sealskin/> accessed 24 October 2016.

131 Bill Justinussen and Randi V. Evaldsen, 'Seal Ban Undermines EU Credibility in Arctic' The Arctic Journal (Nuuk, 15 April 2015).

132 Parliamentary Questions, 'Answer given by Mr Vella on behalf of the Commission' E-000747/2016 (17 March 2016), <http://www.europarl.europa.eu/sides/getAllAnswers .do?reference=E-2016-000747\&language $=\mathrm{EN}>$ accessed 24 October 2016.

133 'Greenland Group in Iqaluit to Partner Against EU Seal Product Ban' свс News (16 January 2015); 'Despite Exemption, NTI [Nunavut Tunngavik Inc.] still opposed EU Seal Skin Ban' NunatsiaqOnline (Iqaluit, 6 August 2015); Inuit Sila Press Release, 'Inuit Seal Hunters Unite in Struggle for International Justice' Arctic Journal (Nuuk, 28 September 2015). 
Since indigenous peoples constitute the core of the Arctic, one can consider the Us as occupying the semi-periphery. While the us government has territory in the Arctic, its history as a colonizing power has been at the forefront of its complicated relationship with sovereign indigenous communities in Alaska. This is one reason that the Us's claims as an Arctic State are not straightforward. Alaska Natives have struggled over a number of decades to assert and define their sovereign power; the us Federal Government and Alaska State Government have each responded accordingly to those claims while still asserting their own authority and addressing their own political needs. As such, us sovereignty in the Arctic is the product of a colonial relationship enacted through a complex domestic legal regime based on administrative, constitutional, corporate, and Alaska Native laws.

The EU can be understood as lying on the periphery of the Arctic because it has an even more limited relationship to territory in the Arctic (through northern Finland and Sweden) and is not a member of the Arctic Council. There are of course limits to comparing the EU to the Us since it does not make any colonial claims over Inuit and other Arctic indigenous peoples. Nonetheless, the EU's new seal regime, like its us counterpart, governs Inuit seal hunts directly effecting how Inuit relate to the land. This strikes at the heart of the Arctic and has threatened international acceptance of the EU as an Arctic player.

If EU politicians and civil servants examine their relationship to the Arctic in terms of sovereign power they are presented with several choices: EU officials may continue down the path of trying to balance animal welfare activist desires, market harmonization regulations, EU Arctic policies, and Inuit livelihood. Thus, they would try to signal to Arctic peoples that they are indeed responsible Arctic actors by taking the time to investigate domestic co-management systems more deeply and systemically, with an acute awareness of Inuit self-determination rights. They would have to invest significant amounts of political and financial resources in order to ensure that the new EU seal regime is implemented in a way that aligns with contemporary Arctic law and politics. ${ }^{134}$

What the study of the us seal regime highlights, confirmed by political reality thus far, is that putting such a scheme into effect is no easy taskand that even if done with the best intentions the process will be fraught with

134 Cf. Shadian, n. 12 above. 
missteps and challenged by popular protest. Even though law is a common way to express power in a way that includes multiple agendas and interests, it does not necessarily resolve ambiguities. Instead it pushes and reshapes political agendas in a particular direction. What the EU may learn from the US and Alaska is that while the new seal regime is the product of resolved court disputes, it is very likely only the beginning of a long, legally complex negotiation with Inuit leaders in Canada and Greenland and will remain a matter of 'unfinished business' for a while. ${ }^{135}$ The EU seal regime, if fully operationalized, will likely be even more complicated than the us seal regime in Alaska since it will be enmeshed in the web of Federal Canadian laws, Nunavut laws, Inuit indigenous laws, the increasingly autonomous legal system of Greenland, ${ }^{136}$ Danish law, wто law, international human rights law, EU law, and the respetive domestic laws of EU Member States.

If $\mathrm{EU}$ officials choose that path they must also live with a particular irony. Under the new law and with the new administrative structures, the EU will be able to claim that they are to some degree addressing Inuit self-determination rights. Take away the irony and all that is left is the EU projecting sovereign power beyond its existing territorial boundaries, and reconfiguring Inuit relationships to seals, land, and water. One key aspect of sovereign power is to determine what is the norm and what, or as in this case who, is the exception. Sovereign power is most often constituted through defining difference and then implimenting law to reconcile with this purported difference. In fact, this was the classic way in which imperial power operated over the past several centuries. Colonizing powers first would legally define indigenous as different or exceptional, then enacted laws that tried to bridge, redefine, or contain that difference. Such a 'dynamic of difference' would justify the enactment of postitive laws and the prescence of the colonizing power. ${ }^{137}$ In Alaska, it was as recent as the early 1970s when the us Federal Government abolished Native claims to land title, only to start anew by redefining the meaning of Native soveriegn hunting rights as an exception to conservation laws.

\footnotetext{
135 See Anderson, n. 42 above.

136 Natalia Loukacheva, The Arctic Promise: Legal and Political Autonomy of Greenland and Nunavut (University of Toronto Press 2007).

137 Antony Anghie, Imperialism, Sovereignty and the Making of International Law (Cambridge University Press 2005); Karin Mickelson, 'The Maps of International Law: Perceptions of Nature in the Classification of Territory' (2014) 27(3) Leiden Journal of International Law 621.
} 
The EU seal regime also enacts this dynamic of difference since it characterizes seal hunting as immoral, bans the importation of seal products thereby killing the market, and then categorizes indigenous hunters as an exception to the ban. The regime attempts to reconcile that indigenous difference and reconstruct the market by creating conditions for Inuit and indigenous hunters 'to place [seal products] on the market.' ${ }^{138}$ This in effect increases the EU's influence in the Arctic since it is now dictaing the rules of the seal market. The new legislation defines indigenous communities as people sharing a history of conquest or colonisation. ${ }^{139}$ But one could also read it as a definition that brings with it the echoes of conquest and colonialism into the present since the EU is also implicitly laying claim that it has the authority to define who is or is not indigenous.

EU officials could also take another path and measure their new seal regime against Inuit sovereign power and presence. In doing so, they would have to account for the fact that their seal regime raises questions of the EU's legitimacy in Arctic politics and international law writ large. With that they would have a series of options. EU officials may do away with distinctions between subsistence and commercial as well as indigenous and non-indigenous, and focus on only allowing seal products that result from hunts that consider the seals' welfare into the European market. These Eu measures would still have to comply with wTo law, but this would be feasible in partnership with exporting countries. This approach would focus on the method of the hunt and not the identity of the hunter. Or EU officials may trust domestic and international legal regimes regulating seal hunts and enforcing standards of humane treatment. ${ }^{140}$ This would mean that the EU would treat Inuit hunting rights, and really all hunting, as the rule leaving it to domestic and international laws to determine

138 New Basic Regulation article 2. See also Elizabeth Whitsitt, 'A Comment on the Public Morals Exception in International Trade and the EC-Seal Products Case: Moral Imperialism' (2014) 3(4) Cambridge Journal of International and Comparative Law 1376; Sellheim, "The Narrated "Other" —Challenging Inuit Sustainability Through the European Discourse on the Seal Hunt' n. 103 above.

139 New Basic Regulation article 1: “other indigenous communities" means communities in independent countries who are regarded as indigenous on account of their descent from the populations which inhabited the country, or a geographical region to which the country belongs, at the time of conquest or colonisation or the establishment of present State boundaries and who, irrespective of their legal status, retain some or all of their own social, economic, cultural and political institutions.'

140 Nikolas Sellheim, 'Seal Hunting in the Arctic States. An Analysis of Legislative Frameworks, Incentives and Histories' (2015) 7 Yearbook of Polar Law 188. 
when such rights offended legal standards of ethical treatment. With that, EU officials may want to abandon their seal regime all together and focus their Arctic efforts on other issues. This would enhance Inuit communities' ability to confront other challenges of everyday life and determine for themselves how they want to build a livelihood from seal hunting. 